\section{Preparative and X-Ray Diffraction Studies on Several Mercury(I) Salts*}

\section{EBBA DORM and BIRGITTA LINDH}

Institute of Inorganic and Physical Chemistry, University of Stockholm, Stockholm, Sweden

Tn connection with studies being conIducted at this Institute on the structural properties of mercury(I) compounds several inorganic and organic salts of this metal have been synthesized. Some of these have not been reported previously in the literature.

Most of the salts were prepared from aqueous solutions of mercury(I) nitrate (pro analysi) made slightly acid with nitric acid and the respective acid or alkali salt of best quality available. When it was necessary to improve the crystallinity of the samples, a diffusion method was applied giving a very slow precipitation process (up to several weeks). All the salts were characterized by their $\mathbf{X}$-ray powder patterns taken in a Guinier camera of $\mathbf{8 0}$ mm diameter with monochromatized $\mathrm{Cu} K \alpha_{1}$ radiation. Further details on the preparative work and tables of the powder photographs have been given elsewhere.1

Structural studies on the basis of singlecrystal data have been performed for some of the compounds and are in progress for a few more. Some of the salts are very slightly soluble and all attempts to prepare crystals for single-crystal work were unsuccessful. A study has been made of the possibility of applying the radial distribution function derived from the $\mathrm{X}$ ray powder data to demonstrate the existence of the $\mathrm{Hg}_{2}{ }^{2+}$ group in such compounds. ${ }^{2}$

The preparative and X-ray powder studies so far performed comprise the following compounds:

Mercury (I) sulphate, $\mathrm{Hg}_{2} \mathrm{SO}_{4}$. The crystals are colourless and the unit cell is monoclinic with dimensions $a=6.2802 \pm$ $9 \AA, b=4.4273 \pm 5 \AA, c=8.367 \pm 2 \AA$, $\beta=91.76 \pm 2^{\circ}$. The measured density is $7.05 \mathrm{~g} / \mathrm{cm}^{3}$. The cell contents are 2 formula units giving a calculated density of 7.10 $\mathrm{g} / \mathrm{cm}^{3}$. The space group is $P c$ (No. 7). The

* Structural Studies on Mercury(I) Com. pounds III. axial ratio and monoclinic angle are in good agreement with the data reported by de Schulten from optical measurements." The crystal structure has been determined using single-crystal data and will shortly be published elsewhere. ${ }^{4}$

Mercury $(I)$ selenate, $\mathrm{Hg}_{8} \mathrm{SeO}_{4}$. The crystals are pale yellow and the monoclinic unit cell has the dimensions $a=$ $6.3507 \pm 9 \AA, b=4.5870 \pm 7 \AA, c=$ $8.499 \pm 2 A, \beta=90.98 \pm 2^{\circ}$. The measured density is $7.14 \mathrm{~g} / \mathrm{cm}^{3}$. With 2 fornula units in the unit cell the calculated density is $7.26 \mathrm{~g} / \mathrm{cm}^{3}$. Single-crystal data have been used to solve the structure of $\mathrm{Hg}_{8} \mathrm{SeO}_{4}$ which has been found to be isomorphous with $\mathrm{Hg}_{8} \mathrm{SO}_{4}{ }^{4}$

Mercury (I) bromate, $\mathrm{Hg}_{8}\left(\mathrm{BrO}_{8}\right)_{2}$. This salt crystallizes as thin colourless plates. The unit cell is monoclinic with the following dimensions $a=18.806 \pm 7 \AA, b=$ $4.4701 \pm 8 \AA, c=8.595 \pm 2 \AA, \beta=$ $107.19 \pm 3^{\circ}$. The measured density is $6.20 \mathrm{~g} / \mathrm{cm}^{3}$. The cell contents are 4 formula units and the calculated density is 6.32 $\mathrm{g} / \mathrm{cm}^{3}$. The space group is $C 2 / \mathrm{c}$ (No. 15). The crystal structure has been determined from single-crystal data. An account of the investigation will shortly appear elsewhere. ${ }^{5}$

Mercury (I) thiocyanate, $\mathrm{Hg}_{2}(\mathrm{SCN})_{2}$. The compound gives extraordinarily thin crystals. The unit cell is orthorhombic with $a=15.714 \pm 1 \AA, b=6.4256 \pm 4 \AA$, $c=6.3765 \pm 5 \AA$. The measured density is $5.21 \mathrm{~g} / \mathrm{cm}^{3}$. With 4 formula units in the unit cell the calculated density is $\mathbf{5 . 3 3}$ $\mathrm{g} / \mathrm{cm}^{3}$. So far, it has not been possible to prepare the thiocyanate in crystals suitable for single-crystal work. An investigation on the basis of the powder data suggests a pronounced structural relationship with the mercury(I) halides. ${ }^{1}$

Mercury $(I)$ acetate, $\left(\mathrm{CH}_{3} \mathrm{COO}\right)_{2} \mathrm{Hg}_{8}$. The crystals are colourless needles. The unit cell is monoclinic with the dimensions: $a=$ $5.185 \pm 2 \AA, b=5.960 \pm 1 \AA, c=12.177$ $\pm 5 \AA, \beta=100.04 \pm 4^{\circ}$. The measured density is $4.67 \mathrm{~g} / \mathrm{cm}^{3}$. With 2 formula units in the cell the calculated density is 4.64 $\mathrm{g} / \mathrm{cm}^{3}$. The possible space groups are $C_{2}$ (No. 5), $C m$ (No. 8), and $C 2 / m$ (No. 12). The data are in accordance with those reported by Puff, Lorbacher and Skrabs. ${ }^{6}$ Mercury (I) o-phthalate, $\mathrm{C}_{6} \mathrm{H}_{4}(\mathrm{COOHg})_{2}$. The salt crystallizes in colourless needles. The symmetry is monoclinic and the unit cell has the dimensions $a=26.33 \pm 2 \AA$, $b=6.255 \pm 1 \AA, c=12.896 \pm 5 \AA, \beta=$ 
$116.94 \pm 3^{\circ}$. The measured density is 4.03 $\mathrm{g} / \mathrm{cm}$. The cell contents are 8 formula units giving the calculated density $3.96 \mathrm{~g} / \mathrm{cm}^{8}$ The space group is $C 2 / c$ (No.15). The crystal structure has been determined from single-crystal data. A full account of this study will shortly be published.?

The following organic salts have also been prepared and characterized by their X-ray powder patterns: Mercury(I)propionate, $\left(\mathrm{C}_{2} \mathrm{H}_{5} \mathrm{COO}\right)_{2} \mathrm{Hg}_{2}$, butyrate, $\left(\mathrm{C}_{3} \mathrm{H}_{7} \mathrm{COO}\right)_{2} \mathrm{Hg}_{2}$, monochloroacetate, $\left(\mathrm{CH}_{2} \mathrm{ClCOO}\right)_{2} \mathrm{Hg}_{2}$, dichloroacetate, $\left(\mathrm{CHCl}_{2} \mathrm{COO}\right)_{2} \mathrm{Hg}_{2}$, and trichloroacetate, $\left(\mathrm{CCl}_{3} \mathrm{COO}\right)_{8} \mathrm{Hg}_{2}$.

The authors wish to thank Professor Arne Magnéli for his kind interest and valuable comments on this work.

The work has been carried out within a research program supported by the Swedish Natural Science Research Council.

1. Dorm, E. and Lindh, B. Univ. Stockholm, Inst. Inorg. \& Phys. Chem., Data and Information Series 27 (1966).

2. Werner, P.-E. and Karlsson, J. Univ. Stockholm, Inst. Inorg. \& Phys. Chem., Data and Information Series 26 (1966).

3. de Schulten, A. Bull. Soc. Franc. Minéral. 26 (1903) 113.

4. Dorm, E. To be published.

5. Dorm, E. Acta Chem. Scand. In print.

6. Puff, H., Lorbacher, G. and Skrabs, R. Z. Krist. 122 (1965) 156.

7. Lindh, B. Acta Chem. Scand. 21 (1967). In press.

Received June 15, 1967.

\section{Intestinal Absorption and Esterification of Vitamin $D_{3}-1,2-{ }^{3} \mathrm{H}$ in Man ROLF BLOMSTRAND and LENNART FORSGREN}

\section{Departments of Clinical Chemistry and Surgery at Serafimerlasarettet, Karolinska Institutet, Stockholm, Sweden}

Usistin sing rats with lymph fistulae, Schachter t al. ${ }^{1}$ have shown that maximal absorp. tion of tritium-labelled vitamin $D_{3}$ takes place in the midjejunum and that its transfer into the blood is mainly via the lymph. Little information exists on the absorption of vitamin $\mathrm{D}$ in man. Kodicek ${ }^{2}$ found that between 13 and $23 \%$ of an oral dose of vitamin $\mathrm{D}_{3}{ }^{14} \mathrm{C}$ was recoverable from the feces of infants within 3 days.

The purpose of the present preliminary study is to show that vitamin $\mathrm{D}_{\mathbf{3}}{ }^{3} \mathrm{H}$ is absorbed via the lymphatic pathway in man and that only a minor portion of the absorbed vitamin $\mathrm{D}_{3} \cdot{ }^{3} \mathrm{H}$ is esterified during the absorption. The results also establish the requirement of bile for vitamin $\mathrm{D}_{3}{ }^{3} \mathrm{H}$ absorption.

Methods. Labelled material. Vitamin $\mathrm{D}_{3} \cdot 1,2{ }^{3} \mathrm{H}$ was obtained from New England Nuclear Corp. Boston, Mass. The studies to be described were performed on patients with diagnosed cancer of different types (Forsgren, ${ }^{3}$ ). The thoracic duct was cannulated by a method described by Werner." The patients were fasted over night before surgery. After the cannulation of the thoracic duct the patients were fed $0.2 \mathrm{mg}$ of tritium-labelled vitamin $\mathrm{D}_{3}$ $(20 \mu \mathrm{C})$ dissolved in $5 \mathrm{~g}$ of olive oil together with $150 \mathrm{ml}$ skim milk. The lymph was collected continuously in serial 2 hour fractions. For a detailed information about the clinical procedures see Forsgren. ${ }^{3}$

Extraction of lymph was carried out as described previously. ${ }^{5}$ The total lipid extract was dissolved in benzene and stored under nitrogen at $-15^{\circ} \mathrm{C}$.

Extraction and chromatography. In each study the time course of the absorption of radioactivity (Fig. 1) was determined by extracting $0.5 \mathrm{ml}$ of each lymph sample with

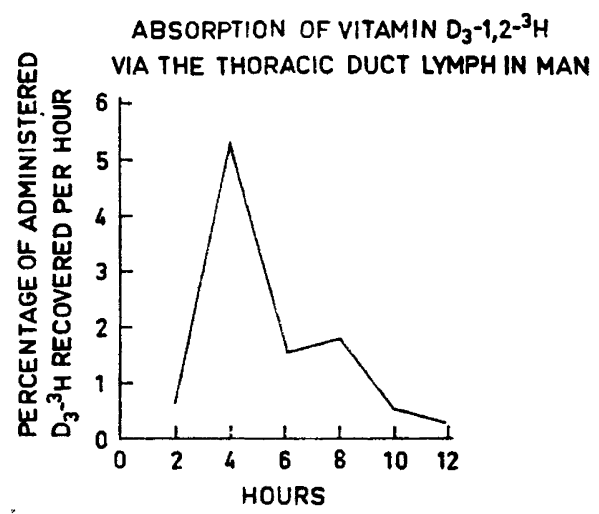

Fig. 1. Appearance of radioactivity in human thoracic duct lymph after feeding vitamin $D_{3}-1,2-{ }^{3} \mathrm{H}$.

Acta Chem. Scand. 21 (1967) No. 6 